\title{
Perempuan dan HAM: Peta Permasalahan dan Agenda Aksi
}

\author{
Trias Setiawati
}

\begin{abstract}
Nowadays the world does not understand human rights as realization the individualism and liberalism. Human rights is viewed as human concept that the rights which are inherent in human nature without debating the background of racism, tenacity, religion etc. The concept above-mentioned is modern one. In this regard, the issue of woman empowerment, in fact, is still becoming marginalized issue in all fields of development. Thus, the using of gender perspective is needed in all policies, for instance in planning, in organizing, in actuating, in coordinating, and in evaluating the cases of evading human rights. For that reason, the role of man is still needs developing in building a prosperous and just society.
\end{abstract}

Pada saat ini, dunia tidak lagi memandang Hak Asasi Manusia (HAM) sekadar sebagai perwujudan paham Individualisme dan Liberalisme seperti dulu. HAM lebih dipahami secara manusiawi sebagai hak-hak yang melekat dengan harkat dan hakikat kemanusiaan, apapun latar belakang ras, etnik, agama, warna kulit, jenis kelamin, usia maupun pekerjaan.

Pemahaman yang lebih manusiawi itulah yang melatarbelakangi konsep. HAM modern sebagai berikut : ${ }^{1}$

Human right is could generally be defined as those rights which are inherrent in our nature and without which we cannot live as human beings.

Hal ini tercantum dalam alinea 8 Preambule dari The Universal Declaration of Human Rights, 1948.

Konsep serta cakupan materi HAM sendiri tumbuh dari waktu ke waktu.
Sampai tahun 1986, sudah ada 67 buah instrumen HAM yang telah diterima secara internasional, sejak dari Slavery Convention -Konvensi tentang Perbudakantanggal 25 September 1962. Daftar ini terus bertambah, setahap demi setahap, instrumen tersebut diratifikasi atau diaksesi oleh negara-negara anggota PBB. Meskipun demikian ratifikasi tersebut tidak dengan sendirinya menegakkan HAM secara konsisten, dan sebaliknya, negara yang belum meratifikasi juga tidak selalu berarti tidak menghormati HAM.

Dalam Mukadimah Piagam Perserikatan Bangsa Bangsa (PBB) yang ditandatangani tanggal 26 Juni 1945, dapat dibaca antara lain bahwa : bangsa-bangsa yang bersatu dalam PBB berketetapan hati atau bertekad supaya generasi-generasi mendatang terhindar dari. bencana peperangan yang telah dua kali mendatangkan penderitaan yang tidak terperikan kepada umat manusia. Para pendiri PBB juga kembali

'Bahar, Saafroedin., 1996, Hak Asasi Manusia Analisis Komas HAM dan Jajaran Hankam/ $A B R I$, Jakarta: Sinar Harapan. 
memperkuat keyakinan atau kesetiaan mereka terhadap HAM, martabat dan nilainilai luhur manusia sebagai pribadi, serta terhadap persamaan hak pria dan wanita, dan persamaan hak dari negara besar dan kecil.

Tujuan PBB dalam pasal 1 tersebut, yaitu mewujudkan kerja sama internasional dalam upaya pemajuan dan peningkatan penghargaan terhadap HAM serta kebebasan-kebebasan dasar untuk semua orang tanpa pembedaan berdasarkan ras, jenis kelamin, bahasa atau agama. Perlu dicatat bahwa pada tahap-tahap pertama ketika naskah piagam ini disusun, pecantuman larangan diskriminasi berdasarkan jenis kelamin tidak ada. Bagian itu baru dimuat berkat desakan dari wakilwakil 42 Lembaga Swadaya Masyarakat (LSM) yang memperoleh pengakuan sebagai peserta dalam pertemuanpertemuan penyusunan Piagam (The United Nations 1945-1996 and the advancement of Women 1995, halaman 10). ${ }^{2}$

Piagam PBB inilah dokumen hukum yang pertama secara tegas memuat persamaan hak dari semua orang, dan menyatakan bahwa diskriminasi berdasarkan jenis kelamin, adalah bertentangan dengan hukum. Meskipun masih diperlukan rumusan-rumusan, dan ukuran-ukuran yang secara internasional disepakati, sehingga dapat terwujud instrumeninstrumen internasional yang diperlukan untuk pemajuan persamaan antara pria dan wanita. Untuk mewujudkan hal tersebut harus ada kesepakatan internasional mengenai cakupan dari hak-hak tersebut dan apa-apa yang diperlukan untuk meningkatkan persamaan pria dan wanita.

Masalah yang dihadapi adalah pembatasan yang terkandung dalam Pasal 2 ayat 7 Piagam PBB yang mengemukakan bahwa PBB tidak mempunyai wewenang untuk mengadakan intervensi terhadap urusan-urusan yang termasuk yuridiksi dalam negeri. Pada tahun-tahun permulaan, umumnya masih terdapat anggapan bahwa pembatasan tersebut juga mencakup masalah HAM. Meskipun PBB telah menghasilkan berbagai instrumen lainnya untuk memberdayakan perempuan yaitu:

1. Convention on Elimination of All Forms of Discrimination Againts Woman (CEDAW) atau Konvensi terhadap Pembatasan Segala Bentuk Diskriminasi terhadap Perempuan, tahun 1979, disebut Konvensi Wanita.

2. World Declaration on Education For All, tahun 1990.

3. Vienna Declaration of Human Right, tahun 1993.

4. Declaration on Violence Againts Woman, tahun 1993.

5. Agenda of World Summit for Social Development, tahun 1993.

6. International Conference on Population and Development Plan of Action, tahun 1994.

7. Plan Form of Action, Hasil Konperensi Beijing, tahun 1995.

8. Nairobi Forward Looking Strategies For the Advancement of Women Toward the Year 2000.

Secara khusus Deklarasi tentang HAM mempunyai sasaran perlindungan yaitu:

1. Kanak-kanak,

2. Kaum Perempuan,

3. Kaum Pekerja,

4. Minoritas,

5. Penyandang Cacat,

6. Penduduk Asli dan Suku Terbelakang,

7. Tersangka, Tahanan dan Tawanan,

8. Budak,

9. Korban Kejahatan,

10. Pengungsi,

11. Mereka yang

Tidak

Berkewarganegaraan.

${ }^{2}$ Ihromi, T.O, Irianto, S. dan Luhulima, A.S. (penyunting)., 2000, Penghapusan Diskriminasi Terhadap Wanita, Bandung: Penerbit Alumni. 
Secara tegas dinyatakan bahwa kanakkanak dan perempuan, yang sering dianggap bukan bagian dari persoalan tindak pelanggaran HAM, karena berada dalam dunia domestik, adalah persoalan HAM juga.

\section{Sejarah Konvensi Wanita}

CEDAW (Convention on Elimination of All Forms of Discrimination Againts Woman) atau Konvensi terhadap Pembatasan Segala Bentuk Diskriminasi terhadap Perempuan atau selanjutnya disebut Konvensi Wanita (KW), telah diterima dalam Sidang Umum PBB tanggal 18 Desember 1979. Indonesia meratifikasi Konvensi tersebut melalui Undang-undang Republik Indonesia Nomor 7 Tahun 1984, tanggal 24 Juli 1984.

Perjalanan KW sendiri amat panjang, mulai dari pembuatan instrumeninstrumen internasional yang dapat digunakan dalam upaya perwujudan hakhak persamaan pria dan wanita serta pencarian berbagai data dan informasi tentang diskriminasi yang terjadi terhadap wanita dalam peraturan-peraturan, maupun dalam praktik yang berlangsung dalam dunia nyata. Pada awalnya $\mathrm{KW}$ bermula dari komisi kedudukan wanita, yang mulanya hanya berstatus sebagai subkomisi, yang menjadi bagian dan wajib melapor kepada Komisi HAM.

Pada bulan Juni 1946, status subkomisi tersebut menjadi Komisi yang langsung dibawah ECOSOC (Economic and Social Council). Komisi kedudukan wanita ini diserahi fungsi untuk mempersiapkan rekomendasi-rekomendasi dan laporanlaporan kepada ECOSOC mengenai pemajuan wanita di bidang-bidang politik, ekonomi, sipil, sosial, dan pendidikan serta membuat rekomendasi tentang masalahmasalah mendesak di bidang hak-hak wanita yang segera harus ditangani. Pada peresmiannya tahun 194.7, Komisi Kedudukan Wanita (KKW) masih menambahkan bahwa mereka akan giat bekerja untuk meningkatkan kedudukan wanita, tanpa membedakan mereka menurut kebangsaannya, ras, bahasa, atau agama untuk memajukan persamaan dengan pria di semua bidang usaha dan untuk meng-hapuskan segala bentuk diskriminasi terhadap wanita berkenaan dengan ketentuan-ketentuan dalam peraturan-peraturan, dalam prinsipprinsip hukum atau atutan-aturan ataupun dalam menginterpretasikan hukum adat (The United Nations 1995, hal.14).

Usulan KKW supaya diadakan suatu survei global mengenai keberadaan hakhak wanita, diterima dalam sidang-sidang ECOSOC. Dalam rangka survei tersebut KKW menyarankan kepada ECOSOC untuk merekomendasikan kepada pemerintah dari negara anggota PBB supaya setiap tahun mengisi kuesioner berisi pertanyaan-pertanyaan tentang kedudukan hukum dari wanita dan tentang perlakuan terhadap wanita. Dalam laporan sekretariat pada tanggal 16 Desember 1947 disebutkan bahwa tanggapan berbagai negara sangat menggembirakan; dan ada 74 negara yang mengisi kuesioner, 25 negara di antaranya tidak memberi hakhak politik kepada warga negara wanita, jumlah wanita yang buta huruf lebih besar dari pria.

Informasi-informasi dari survei global tadi digunakan untuk membuat resolusi yang dalam banyak hal berisi permintaan kepada para pemerintah anggota PBB untuk mengubah peraturan-peraturan yang diskriminatif. Di samping digunakan untuk menjadi dasar legitimasi bagi pembuatan perjanjian-perjanjian internasional tentang hak-hak yang setara antara pria dan wanita dalam berbagai bidang, termasuk hak-hak politik. Termasuk di antaranya adalah instrumen mengenai penghapusan diskriminasi terhadap wanita, yang telah diterima pada Sidang Umum PBB pada tanggal 7 Nopember 
1967. Instrumen ini memuat suatu daftar dari bidang-bidang tertentu dan dituntut persamaan hak-hak pria dan wanita yang harus diwujudkan secara hukum dan dalam praktik kehidupan sehari-hari.

Deklarasi bukanlah instrumen yang memiliki daya mengikat, tetapi umum menganggap bahwa pernyataan Deklarasi memproklamasikan bahwa diskriminasi terhadap wanita, secara fundamental, tidaklah adil dan merupakan pelanggaran terhadap wanita. Deklarasi memang mendorong gerakan untuk memperjuangkan hak-hak wanita, tetapi dalam praktik dampaknya sangat terbatas. Kebutuhan akan instrumen yang mengikat, yaitu suatu konvensi yang merumuskan hak-hak wanita semakin dirasakan. ECOSOC meminta KKW untuk menyusun rancangan Konvensi Penghapusan Diskriminasi terhadap Wanita. Penyusunan dimulai pada tahun 1974. Rancangan yang dihasilkan memuat : mukadimah, ketetentuan-ketentuan umum -termasuk definisi diskriminasi terhadap wanita- dan tiga seksi yang memuat substansi politik, sosial ekonomi, serta hak-hak keluarga. Komisi mengedarkan ke 40 pemerintah yang kemudian mengirim respons berisi usulan-usulan perubahan. Juga datang saran dari empat badan internasional lainnya serta 11 LSM.

Rancangan Konvensi oleh Komisi Kedudukan Wanita dikirim ke sidang ECOSOC untuk disetujui pada tanggal 17 Desember 1976. Konsensus sukar dicapai terutama mengenai penghapusan diskriminasi terhadap wanita di bidang hukum, hak-hak dalam perkawinan dan keluarga, dalam pendidikan, dalam ketenagakerjaan dan pembangunan pedesaan. Namun akhirnya pada tanggal 18 Desember 1976, konvensi ini diterima di Sidang Umum dengan 130 negara setuju, dan 11 negara abstain.

Konvensi Penghapusan Diskriminasi terhadap Wanita akhirnya diterima pada
Sidang Umum PBB pada tanggal 18 Desember 1979. Di Indonesia sendiri konvensi ini diratifikasi melalui Undangundang Nomor 7 Tahun 1984 dan diundangkan di Jakarta pada tanggal 24 Juli 1984.

Selama 10 tahun sesudahnya, yakni pada tahun 1994, sejumlah wanita yang terdiri dari para pengajar, aktivis sejumlah LSM perempuan setelah menyelenggarakan suatu lokakarya tentang Wanita Dalam Politik membentuk kelompok kerja Covention Watch. Mereka adalah para pengajar pada Program Studi Kajian Wanita Program Pascasarjana UI, anggota sejumlah LSM Perempuan, LBH di Jakarta dan Yayasan Lembaga Konsumen Indonesia. Pada tahun 1994, 1995 dan 1996 kelompok ini telah menyelenggarakan berbagai kegiatan seperti seminar, ceramah melalui siaraan radio dan televisi untuk lebih mensosialisasikan substansi dari Konvensi wanita dengan penekanan pada Pasal 11, yaitu ketentuan tentang berbagai hak di bidang ketenagakerjaan. Juga penelitian tentang seberapa jauh warga masyarakat mengetahui tentang Konvensi Wanita, dan khususnya pasal 11, dan juga memperoleh informasi tentang perlakuan yang diskriminatif terhadap wanita berkenaan dengan hak-haknya di bidang ketenagakerjaan. Dari hasil penelitiannya diketahui bahwa tidak terlalu banyak orang yang mempunyai kesadaran tentang Konvensi Wanita, seperti misalnya di kalangan para penegak hukum.

Demikian pula akhirnya terbentuk Komisi Nasional Perempuan (KOMNAS Perempuan) yang diketuai Oleh Prof. Saparinah Sadli pada tahun 1998 di Jakarta. Institusi yang diharapkan dapat lebih berdaya untuk mengurangi tindak pelanggaran HAM terhadap perempuan, baik dalam jangka pendek maupun dalam jangka panjang, dengan berbagai tindakan praktis maupun sekaligus yang strategis. 


\section{Peta Permasalahan}

Untuk lebih jelas melihat peta permasalahan perempuan dan HAM akan dilihat berbagai hasil pertemuan yang memberikan catatatan penting masalah perempuan. Salah satu yang penting adalah hasil Konperensi Beijing (1995) yang memberikan catatan atas permasalahan perempuan sebagai berikut: ${ }^{3}$

1. Perempuan dan Kemiskinan

2. Pendidikan dan Pelatihan Perempuan

3. Perempuan dan Kesehatan

4. Kekerasan terhadap Perempuan

5. Perempuan dan Konflik Bersenjata

6. Perempuan dan Ekonomi

7. Perempuan dan Kekuasaan dan Pengambilan Keputusan

8. Mekanisme-mekanisme Kelembagaan bagi Kemajuan Perempuan

9. Hak-hak Asasi Perempuan

10. Perempuan dan Media

11. Perempuan dan Lingkungan Hidup

12. Anak-anak Perempuan

Program Utama Nasional untuk Penelitian Peningkatan Peranan Wanita (PUNAS P2W) dalam PELITA VI, yang masih dijadikan pedoman penelitian kajian wanita sampai saat ini, memberikan catatan atas berbagai permasalahan perempuan sebagai berikut:4

1. Kebutuhan Dasar Wanita

a. Pendidikan Kaum Wanita

b. Kesehatan Wanita

c. Pangan dan Gizi Wanita

d. Perumahan dan Lingkungan Hidup

2. Wanita dan Kegiatan Ekonomi

a. Peningkatan Keahlian, Ketrampilan dan Etos Kerja Wanita

b. Peningkatan Peluang dan Kualitas
Usaha bagi Wanita

c. Peningkatan Upah, Peluang Jabatan dan Pengembangan Karir bagi Pekerja Wanita

d. Peningkatan Jaminan Sosial, Perlindungan Hukum dan Perlindungan Kerja bagi Wanita

3. Peningkatan Kualitas Peran Ganda Wanita sebagai Mitra Sejajar Pria dalam Keluarga dan Masyarakat

a. Pembangunan yang berwawasan Kemitrasejajaran Pria dan Wanita berdasarkan Pendekatan Jender

b. Perlakuan Subordinatif terhadap Wanita

c. Peran Ganda Wanita

d. Pengembangan Data dan Informas Berwawasan Jender

4. Wanita dan IPTEK

a. Peningkatan Peranan Wanita dalam IPTEK

b. Pengembangan IPTEK untuk Wanita 5. Agama dan Sosial Budaya

a. Agama dalam mendukung Kemitrasejajaran Pria dan Wanita

b. Peningkatan dan Pemantapan Organisasi Kemasyarakatan Wanita.

Garis Besar Haluan Negara (GBHN) 1999 Bab IV bagian $f$ tentang Kebijakan Sosial Budaya item nomor 3 mengenai Kedudukan dan Peranan Perempuan berbunyi sebagai berikut:

1. Meningkatkan kedudukan dan peranan perempuan dalam kehidupan berbangsa dan bernegara melalui kebijakan nasional yang diemban oleh lembaga yang mampu memperjuangkan terwujudnya kesetaraan dan keadilan jender.

2. Meningkatkan kualitas peran dan kemandirian organisasi perempuan dengan tetap mempertahankan nilai

3Anonim. Tth. Landasan Aksi dan Deklarasi Beijing Persamaan Pembangunan Perdamaian. Forum Komunikasi Lembaga Swadaya Masyarakat untuk Perempuan dan Asosiasi Perempuan Indonesia untuk Keadilan.

${ }^{4}$ Anonim, 2000, Rencana Induk Pembangunan Nasional Pemberdayaan Perempuan $2000-$ 2004, Kantor Menteri Negara Pemberdayaan Perempuan RI, Jakarta, April. 
persatuan dan kesatuan serta nilai historis perjuangan kaum perempuan dalam rangka melanjutkan usaha pemberdayaan perempuan serta kesejahteraan keluarga dan masyarakat.

Rencana Induk Pembangunan Nasional (RIPNAS) Pemberdayaan Perempuan $2000-2004$ adalah sebagai berikut:

1. Visi: Kesetaraan dan Keadilan. Jender dalam kehidupan berkeluarga, bermasyarakat, berbangsa, dan bernegara.

2. Misi: Peningkatan kualitas hidup perempuan di berbagai bidang strategis; penggalakan sosialisasi kesetaraan dan keadilan Jender; pengahpusan segala bentuk tindak kekerasan; penegakan hak asasi manusia (HAM) bagi perempuan; pemampuan dan peningkatan kemandirian lembaga dan organisasi perempuan.

\section{Tujuan :}

a. Meningkatkan kedudukan dan peranan perempuan di berbagai bidang kehidupan, berkeluarga, bermasyarakat, berbangsa dan bernegara.

b. Meningkatkan peranan perempuan sebagai pengambil keputusan dalam mewujudkan kesetaraan dan keadilan jender.

c. Meningkatkan kualitas peran dan kemandirian organisasi perempuan dengan tetap mempertahankan nilai persatuan dan kesatuan.

d. Meningkatkan komitmen dan kemampuan semua lembaga yang memperjuangkan kesetaraan dan keadilan jender.

e. Mengembangkan usaha pemberdayaan perempuan dan kesejahteraan keluarga serta masyarakat.

\section{Sasaran:}

a. Terwujudnya peningkatan kualitas SDM. perempuan, kedudukan, dan peranan perempuan termasuk dalam perumusan kebijakan dan pengambilan keputusan secara adil dan proporsional di berbagai bidang kehidupan.

b. Tercapainya peningkatan kualitas peranan pengelolaan dan kemandirian organisasi perempuan dan komitmen masyarakat dalam pemberdayaan perempuan.

c. Terwujudnya kesadaran, kepekaan dan kepedulian jender seluruh masyarakat terutama perumus kebijakan, pengambil keputusan, perencana, dan penegak hukum di semua tingkatan dan segenap aspek pembangunan.

d. Tercapainya peningkatan kesadaran kritis masyarakat tentang perbedaan kebutuhan, minat, aspirasi, dan kepentingan perempuan.

e. Terwujudnya pembangunan sektor yang berperspektif jender melalui upaya pengarusutamaan (mainstreeming) jender yang dimulai dari tahap perencanaan, pelaksanaan, monitoring, dan evaluasi baik di tingkat pusat maupun daerah.

f. Terwujudnya perubahan dan pembaharuan produk hukum dan peraturan perundang-undangan dan nilai-nilai sosial budaya yang kondusif untuk kesetaraan dan keadilan jender.

g. Tercapainya penurunan kemiskinan dalam keluarga dan masyarakat melalui pemberdayaan perempuan di berbagai bidang kehidupan.

\section{Ketidakadilan Jender yang Dialami Perempuan}

Pada kenyataannya perempuan banyak mengalami masalah dalam kehidupannya; baik itu berkaitan dengan dirinya, keluarganya (anak, suami, orang tua, mertua, keluarga batih), lingkungan sosial maupun dunia sekitarnya. Secara mudah orang sering menyatakan bahwa bolehlah perempuan menjadi apa saja, asal tidak 
meninggalkan kodratnya sebagai ibu, sebagai istri, dan sebagai anggota masyarakat. Benarkah itu semua adalah kodrat perempuan?

Kodrat adalah-suatu pemberian Allah SWT yang diberikan kepada manusia yang tidak dapat diubah oleh teknologi yang paling canggih sekalipun. Hal yang kodrati pada perempuan adalah apa yang dimiliki oleh perempuan dan tidak dapat dipertukarkan dengan kaum laki-laki. Ketika membicarakan kodrat inilah dikenal istilah seks atau jenis kelamin yaitu kodrat Tuhan yang tidak dapat dipertukarkan dan tidak dapat diubah oleh manusia sebagai makhluk ciptaan Tuhan meskipun teknologi kedokteran telah maju dengan pesat 5

Dari istilah seks atau jenis kelamin inilah akhirnya dikenal ada 'jenis kelamin' secara kodrati, tetapi ada pula 'jenis kelamin' secara kultural atau piskologis yang disebut jender. Jender merupakan sifat yang melekat pada laki-laki dan perempuan yang dikonstruksi secara sosial budaya atau sering disebut kodrat budaya. ${ }^{6}$

Peran jender adalah peran yang berkaitan dengan sifat maskulinitasfeminitas yang melekat pada pria wanita yang dikonstruksi secara sosial maupun kultural'. Sejarah perbedaan jender antara pria dan wanita terjadi melalui proses yang sangat panjang. Perbedaan itu dibentuk, disosialisasikan, diperkuat bahkan dikonstruksikan secara sosial, kultural melalui ajaran agama -bahkan oleh negara. Dengan demikian konsep tentang jender ini terkadang telah mejadi satu stereotipe yang sangat mempengaruhi seorang individu dalam bersikap serta bertingkah laku dalam lingkungannya. ${ }^{8}$

Bem (Cook, 1982) mengemukakan sebuah fenomena yang disebut androgini. Androgini merupakan percampuran antara karakteristik maskulin dan feminin yang seimbang dalam taraf yang tergolong cukup tinggi pada diri seseorang. ${ }^{9}$ Menurut Spencer dan Helmreich (Donelson \& Gullahom, 1977), individu androgin memiliki harga diri yang lebih tinggi, lebih fleksibel dan lebih efektif dalam hubungan interpersonal..$^{10}$

Setiap individu sesungguhnya memiliki kedua karakteristik maskulin dan feminin. Jung memperkenalkannya melalui konsepnya tentang arketipe yaitu anima dan animus. Anima adalah prinsip kewanitaan tak sadar pada pria, sedangkan animus adalah prinsip kepriaan tak sadar pada wanita. Perwujudan arketipe tersebut dipengaruhi oleh faktor budaya dan psikologis. Faktor-faktor tersebut akan mempengaruhi perwujudan karakteristik maskulin-feminin pada diri individu (Barnhause, 1988).11

Menurut Waiten (1992), pemahaman tentang peran jender terbentuk melalui tiga proses, operant conditioning, observational learning, self-socialization. ${ }^{12}$ Selfsocialization berkembang melalui tiga tahap, yaitu: (a) anak belajar

5Mary Astuti., 1997, “Jender dan Pembagunan”, makalah, Penataran Metodologi Kajian Perempuan Berperspektif Jender, Dirjen Dikti, Yogyakarta.

Ibid.

'Fakih, M., 1995, Menggeser konsep gender dan transformasi sosial, Yogyakarta: Pustaka Pelajar.

sIbid.

'Cook, EP., 1982, Psychological Androgyny, New York: Pergamon Press.

'Donelson, E., \& Gullahom, J.E., 1977, Women: A Psychological perspective. New York: John Wilwy and Sons, Inc.

"Barnhause, R. T., 1988, Identitas Wanita, Yogyakarta: Kanisius.

"Weiten,W., 1992, Psychology: Themes and Variations. California Brooks/Cole Publishing Company. 
mengklasifikasikan dirinya sebagai pria atau wanita dan memahami jenis kelaminnya sebagai sesuatu yang permanen, (b) anak melakukan penilaian terhadap karakteristik dan perilaku yang berkaitan dengan jenis kelaminnya, (c) mereka mengusahakan perilaku yang tetap sesuai dengan peran jender yang dianggap tepat dalam budayanya.

Peran jender menjadi sangat bervariasi dalam pola kehidupan tiap orang, tiap keluarga juga tiap budaya maupun negara. Namun budaya yang cenderung sangat patriarkhis sering menimbulkan ketidakadilan jender, yang cenderung merugikan kaum perempuan. Ketidak adilan jender terwujud dalam hal-hal berikut: ${ }^{13}$

1. Marginalisasi, peminggiran peran kaum perempuan; kaum perempuan dianggap sebagai warga masyarakat kelas dua. Perempuan sendiri cenderung enggan menjadi orang nomor satu, karena takut dijauhi atau dicela kaum laki-laki (cinderella complex), perempuan lebih memilih jadi subordinat laki-laki.

2. Stereotipe. Masyarakat mempunyai norma tertentu tentang perempuan yang ideal yaitu feminin, sementara lakiláki adalah maskulin, padahal terjadi pada kenyataannya setiap orang memiliki dua karakteristik sekaligus (androgin), yaitu feminin sekaligus maskulin. Dalam kehidupannya sebagai suatu stereotipe, perempuan diharapkan menjadi figur yang feminin: lembut, halus, teliti, rajin, patuh, taat, cantik, cermat dsb, sementara laki-laki diharapkan menjadi figur yang maskulin: gagah, perkasa, gentleman, kuat, cerdas, kasar, memimpin, macho, dsb. Padahal secara psikologis orang yang androgen secara seimbang memiliki banyak kelebihan -seperti harga diri yang lebih tinggi, kemampuan berkomunikasi yang lebih efektif, dan lebih fleksibel. Dalam setiap individu besarnya kadar feminitas maupun maskulinitas sangat variatif antara satu orang dengan orang lain. Meskipun kemudian ada yang lebih memperdalam lagi menjadi feminitas positif dan feminitas negatif, serta maskulinitas positif dan maskulinitas negatif

3. Beban Ganda. Pembagian kerja di dunia domestik untuk perempuan, sementara laki-laki di sektor publik, sehingga ketika perempuan pergi ke sektor publik ada beban ganda yang disandangnya. Beban ganda ini sebagian besar dijalani oleh kaum perempuan sementara semestinya ada juga beban ganda juga untuk kaum laki-laki, karena memang pekerjaan domestik bukanlah kodrat perempuan.

4. Kekerasan. Perempuan dengan fungsi reproduksinya sering mengalami kekerasan di tempat kerja atau bahkan di dalam rumah tangga sendiri. Mulai dari kekerasan fisik, psikis dan seksual. Juga kekerasan yang dilakukan oleh individu, institusi maupun negara. Dalam rumah tangga perempuan dianggap tidak produktif, sehingga harus menuruti kemauan laki-laki si pencari nafkah utama, padahal kenyataannya tidak selalu demikian. Dalam dunia publik, di tempat kerja perempuan yang haid, mengan-dung, melahirkan, menyusui, sering tidak memperoleh haknya secara wajar. Bahkan sering mengalami intimidasi untuk dikeluarkan. Sementara dalam tingkat negara, kadang kekerasan yang diderita perempuan sering tidak tampak di mata publik, karena terjadi di sektor domestik. Kadang perempuan yang mengalami tindak kekerasan dipersalahkan publik, karena perempuan tersebut berdandan menor ataupun

अIbid. 
sebab lainnya yang lebih disebabkan, karena ia berjenis kelamin perempuan.

\section{Pelanggaran HAM Perempuan: di Rumah dan di Luar Rumah}

Kata pelanggaran HAM sendiri, dapat diterjemahkan secara lebih khusus dalam kehidupan perempuan, mungkin tidak menjadi korban pelanggaran HAM bagi kaum laki-laki tetapi menjadi korban pelanggaran HAM bagi perempuan dan membawa derita sepanjang kehidupannya. Secara luas, istilah tindakan pelanggaran HAM sendiri lebih banyak dikaitkan dengan sifatnya yang massal.

Beberapa fenomena dalam masyarakat menunjukkan berbagai kasus pelanggaran HAM yang dialami kaum perempuan. Pelanggaran HAM dapat dialami perempuan secara individual, tidak selalu secara massal, bisa dialami dalam ranah domestik (dalam rumah) maupun di ranah publik (di luar rumah). Khusus untuk pelanggaran HAM domestik, para pelaku bisa individu, kelompok, organisasi maupun negara; demikian juga dalam ranah publik.

Sebagaimana pendapat Shinta Nuriyah, mantan Ibu negara RI:

"Tanpa bermaksud membesarbesarkan masalah atau memperkeruh suasana, saya menyadari sepenuhnya masih banyak terjadi kekerasan di berbagai tempat di Indonesia ini. Mulai dari pelecehan seksual, penganiayaan, diskriminasi, perkosaan hingga pembunuhan. Pelakunya pun bisa bermacam-macam, mulai dari ayah, ibu, saudara, orang lain, masyarakat hingga keterlibatan negara di dalamnya. Sementara itu, korbannya pun bisa sangat beragam tanpa mengenal usia, etnis, suku, latar belakang sosial-ekonomi, maupun profesi". ${ }^{14}$

Dalam dua buku "Di Balik Tirai Tabu" terbitan P'T Kedaulatan Rakyat, digambarkan seluk beluk permasalahan kekerasan yang dialami perempuan dalam rumah. Sementara buku "Ketika Ranting Patah" di antaranya juga dijelaskan bagaimana tindak pelanggaran HAM dapat terjadi juga di tempat kerja. Dalam rumah tangga, perempuan karier sering mendapatkan perlakuan yang kurang menyenangkan dari suami dan anakanaknya, karena dianggap kurang perhatian terhadap kebutuhan suami dan anak. Terlebih lagi jika penghasilan suami di bawah penghasilan istri. Demikian halnya di tempat lain, di mana perempuan bekerja mereka selalu dipandang sebelah mata. ${ }^{15}$ Sebaliknya kaum perempuan tak pernah curiga, apalagi protes terhadap keberhasilan yang diperoleh laki-laki dalam dunia kerja. Perilaku dan sikap yang diterima perempuan lebih sering diakibatkan dari adanya rasa jealous dan inferior, rendah diri pada orang lain. ${ }^{16}$

Betapa perempuan selalu menjadi pihak yang lemah dan dipersalahkan setiap kali terjadi domestic-violence (kekerasan dalam rumah tangga). ${ }^{37}$ Kekerasan dalam rumah tangga (KDRT) yang menimpa perempuan dan anak selama ini sulit untuk dijamah oleh proses hukum. Hal terjadi lantaran banyak faktor yang menghambat

${ }^{14}$ Nuriyah, Sinta., Kata Sambutan Buku Negara dan Kekerasan terhadap Perempuan, Pengantar Kartini Syharir, Penerbit Yayasan Jurnal Perempuan, Jakarta, 2000.

15Anonim., 2000, Perempuan Karir Paling Mudah Terkena Problema Perkawinan, http:// www.detik.com/, 27 Agustus.

${ }^{16}$ Ibid.

${ }^{17}$ Arifin, Nurul., 2000, Puisi pada Ceramah pada Acara Nugerah Perempuan dan Peluncuran Buku: Negara dan Kekerasan terhadap Perempuan, http://www.detik.com/ bintang>bisik-bisik, 21 Juni. 
seperti budaya, privacy dan sosial. ${ }^{18}$ Selama ini korban KDRT, terutama kaum istri dan anak, tidak pernah melaporkan penganiayaan tersebut sebagai sebuah kejahatan. Padahal kekerasan merupakan salah satu bentuk kejahatan. ${ }^{19}$ Seringkali penganiayaan yang diterima istri maupun anak tidak diungkap, sebab berkaitan dengan nama baik keluarga, akibatnya superioritas laki-laki terhadap perempuan semakin meningkat dan akhirnya bermuara pada 'penjajahan' laki-laki terhadap perempuan; hal tersebut merupakan pelanggaran HAM. $^{20}$ Faktor kultural, budaya di Indonesia memposisikan kedudukan suami sebagai orang nomor satu dalam keluarga, akibatnya kedudukan yang nomor satu itu, membuat suami sebagai orang yang harus dituruti segala kemauannya. Hal ini sering membuat suami berlaku sewenang-wenang terhadap istri, dalam hal ini advokasi perlu dilakukan tetapi kadang korban sulit ditemukan karena tidak melaporkan. ${ }^{21}$

Berdasarkan data kasus selama semester pertama tahun 2000, keterlibatan kaum pria dalam ikut menyelesaikan masalah kekerasan terhadap perempuan masih sangat minim, yakni 0,49 persen. ${ }^{22}$ Sementara itu jumlah kekerasan terhadap perempuan selama bulan Januari hingga Juli 2000 mencapai 206 kasus; meliputi tindak kekerasan seperti pelecehan seksual dan perkosaan. Daerah yang paling banyak terjadi kasus ini antara lain Kota Yogyakarta 63 kasus, Bantul 23 kasus, Solo 61 kasus dan Tegal 15 kasus. Sebanyak 88 kasus atau sekitar 43 persen terhadap perempuan yang bekerja, 95 kasus atau 46 persen tidak bekerja dan sisanya 23 kasus atau 11 persen tidak diketahui.. ${ }^{23}$ Tingkat pendidikan korban kekerasan terhadap perempuan taman kanak-kanak ada tiga kasus, SD delapan kasus, SLTP 16 kasus, SLTA 44 kasus dan perguruan tinggi 44 kasus; dan yang tidak diketahui mencapai 87 kasus. $^{24}$

Tindak pelanggaran HAM terhadap perempuan juga dapat dialami oleh perempuan dalam rumah oleh pelaku yang kadang suaminya sendiri. Sebagaimana terlihat dalam data berikut: Setiap tahun sebanyak dua juta kasus aborsi terjadi di Indonesia. Dari jumlah itu, 750 ribu di antaranya dilakukan oleh remaja putri. ${ }^{25}$ Ini berarti jika aborsi dilakukan oleh selain remaja putri, maka ini dapat diartikan dilakukan oleh kaum ibu yang notebene mempunyai suami. Kegagalan dalam penggunaan kontrasepsi sering menjadi penyebab seorang istri terpaksa melakukan aborsi baik karena kemauan sendiri yang disebabkan tuntutan norma Keluarga Berencana (KB), ataupun disuruh suami agar fungsi recreation tetap dapat terus berjalan tanpa ada kaitannya dengan fungsi creation dalam perkawinan. Ataupun alasan-alasan lainnya seperti alasan ekonomi -termasuk kemiskinan- dan alasan-alasan lainnya.

\section{Kekerasan Negara pada Kaum Perempuan}

Tindak pelanggaran HAM, seperti halnya berbagai kerusuhan yang terjadi di

${ }^{18}$ Fuad, Chairil., 2000, Kekerasan Rumah Tangga Sulit Terjerat Hukum, makalah dalam Seminar dan Lokakarya Pentingnya Perlindungan Bagi Korban Kekerasan dalam Rumah Tangga, http: //www.detik.com/Politik dan Peristiwa. 3 Juni.

19 Ibid.

${ }^{20}$ Ibid.

${ }^{21}$ Ibid.

${ }^{22}$ Anonim., 2000, GKR Hemas Menangis, Kota Yogyakarta Banyak Praktek Prostitusi, http: //www.detik.com/Politik dan Peristiwa, 27 Agustus.

23 Ibid.

24 Ibid. 
Indonesia, selain dipicu oleh soal SARA, juga banyak yang diakibatkan oleh ketidakadilan dan kecemburuan distribusi ekonomi. Akibat dari permasalahan tersebut sering mengakibatkan prasangka sosial di masyarakat, sehingga selalu berpandangan negatif terhadap segala sesuatu yang berkaitan dengan persoalan masyarakat. ${ }^{26}$

Karakter dan nation building dapat menjembatani segala macam perbedaan identitas yang memang melekat dalam kehidupan masyarakat Indonesia. Namun ironisnya rezim Orde Baru telah menggunakannya sebagai alat kontrol dan alat untuk melakukan represi, serta mempertajam kelas sosial dengan cara memberikan previlege tertentu pada pengelompokkan atas dasar kelas, agama dan bahkan jender. ${ }^{27}$

"Kekerasan negara bisa disebabkan oleh diamnya negara saat perempuan diperlakukan semena-mena. Negara tidak berbuat apa-apa melihat perempuan ditindas. ${ }^{28}$ Di mana-mana, hampir di semua negara, perempuan kerap menjadi korban pemukulan, perkosaan dan kekerasan lain dalam berbagai bentuk". ${ }^{29}$

Perempuan ternyata paling menderita saat terjadi konflik di Indonesia. Pasalnya, saat terjadi konflik, perempuan, terutama kaum ibu, paling banyak menanggung akibatnya..$^{30}$ Penderitaan itu tidak hanya dialami secara fisik, namun juga secara mental akibat trauma konflik yang diterimanya, bahkan beban ekonomi keluarga dan anak-anak juga turut ditanggungnya. Trauma tersebut juga akan menghantui secara terus menerus sepanjang hidupnya, kekerasan demi kekerasan yang mereka rasakan setiap harinya baik saat konflik maupun di kamp pengungsian membuat mereka getir dalam menghadapi kehidupan selanjutnya. ${ }^{31}$ Namun di luar itu, justru kaum perempuan yang paling tabah dan sabar menghadapi konflik, terbukti kaum ibu tidak pernah larut dalam konflik, walaupun kenyataannya penderitaan yang mereka rasakan lebih besar dari kaum laki-laki. ${ }^{32}$

Kekerasan dalam kerusuhan juga sering mengakibatkan korban tindak pelanggaran HAM berkepanjangan. Misalnya, kasus perkosaan di daerah konflik. Tidak dapat disangkal bahwa kasus perkosaan terhadap perempuan yang kebanyakan beretnis Tionghoa, di Jakarta pada saat kerusuhan bulan Mei 1998, telah membuka sebuah ruang publik yang memungkinkan ceritacerita kekerasan seksual yang terjadi di berbagai tempat di Indonesia muncul di permukaan, sebut saja Aceh. Cerita-cerita tentang perkosaan, penghilangan, penangkapan dan eksekusi sewenangwenang di Aceh tak dapat dibendung lagi. Di Timor Timur (sebelum menjadi negara

${ }^{25}$ Anonim., 2000, Khofifah Indar Parawansa: Tiap Tahun 2 Juta Kasus Aborsi, http: // www.detik.com/Politik dan Peristiwa, 15 Pebruari.

${ }^{26}$ Nursyahbani K, Ketidakadilan dan Isu SARA Ciptakan Kerusuhan, http: //www.detik.com/ Politik dan Peristiwa, 21 Juni 2000.

${ }^{27}$ Ibid.

${ }^{28}$ Mely. G.Tan., Ceramah pada Acara Nugerah Perempuan dan Peluncuran Buku : Negara dan Kekerasan terhadap Perempuan, http://www.detik.com/ bintang>bisik-bisik, 21 Juni 2000

${ }^{29}$ Nuriyah, Sinta., 2000,Ceramah pada Acara Nugerah Perempuan dan Peluncuran Buku! Negara dan Kekerasan terhadap Perempuan, http://www.detik.com/ bintang>bisik-bisik. 25 April.

30 Parawansa, Khofifah Indar., 2000, dialog Menneg PP RI dengan Gubernur Kalbar, http: /www.detik.com/Politik dan Peristiwa, 15 Desember, 15 Desember.

${ }^{31}$ Ibid.

${ }^{2}$ Ibid. 
Merdeka-pen) juga terjadi hal yang sama. Sebuah organisasi perempuan Timor Timur mengumpulkan cerita-cerita perkosaan dan kekerasan terhadap perempuan. Kemudian di Irian Jaya, perempuan asli mulai memberikan kesaksian terhadap perkosaan yang dilakukan oleh aparat militer pada saat diberlakukannya operasi militer. ${ }^{33}$

Ketika perempuan menjadi tulang punggung perekonomian keluarga, baik karena suami di-PHK, menjadi korban kerusuhan, kecelakaan maupun karena kesempatan kerja yang semakin terbatas untuk laki-laki, tak sedikit di antaranya pergi ke luar negeri menjadi Tenaga Kerja Wanita (TKW). Derita dan siksaan mereka terima, meskipun mereka sering disanjung sebagai 'pahlawan devisa'. Pahlawan devisa itu kini banyak yang menjadi 'pahlawan devisa yang teraniaya'. Dalam enam bulan terakhir di tahun 2000, Solidaritas Perempuan mendapatkan pengaduan dari 664 orang. Delapan di antaranya korban perkosaan dan pelecehan seksual, enam orang kekerasan fisik hingga menderita cacat seumur hidup, tiga orang meninggal dunia, tiga orang dipenjara, 29 orang gaji tidak dibayar dan PHK sepihak, 15 orang hilang kontak, dan 600 orang lebih kasus penipuan calon-calon buruh migran dalam negeri. ${ }^{34}$

Menurut Saparinah Sadli, ketua Komnas Perempuan, meskipun antara tahun 19941997 devisa yang datang dari buruh migran yang bekerja di Arab Saudi sekitar 1 milyar USD, ${ }^{35}$ namun hal tersebut memerlukan pertimbangan lain yaitu perlindungan yang konkrit pada TKW. Kurun waktu tahun 1994-1999 buruh migran perempuan mencapai 70 persen dari total 1,4 juta buruh migran, dan 90 persen dari buruh perempuan bekerja di sektor domestik sebagai pembantu rumah tangga. ${ }^{36}$ Buruh migran paling rentan terhadap masalah kekerasan dan pelanggaran HAM, mereka berada pada situasi kerja yang eksploitatif, upah di bawah standar, jam kerja panjang, tanpa jaminan sosial dan pemeliharaan kesehatan. Kekerasan (fisik, psikis dan seksual) kerap dilakukan oleh majikan adalah sebagian bentuk pelanggaran HAM yang dialami. Beberapa di antara mereka pulang dalam keadaan sakit, tubuh penuh luka, stress hingga gangguan psikologis lain ${ }^{37}$.

Menjadi hak setiap warga negara untuk mencari nafkah di luar negeri, tetapi adalah menjadi tanggung jawab negara untuk ikut menjamin bahwa mata pencaharian itu tidak menjerumuskan mereka ke dalam lembah kegelapan dan kesengsaraan. Sebanyak 22 LSM sempat mengunjungi Menteri Tenaga Kerja untuk menyatakan tuntutan mereka agar Pemerintah menghentikan pengiriman tenaga kerja ke Arab Saudi selama tiga bulan, sejak 17 Agustus. ${ }^{38}$

Tenaga kerja wanita pembantu rumah tangga (TKW PRT) yang mengalami kekerasan di Arab Saudi selama dua tahun terakhir meningkat 100 persen. Jika pada tahun 1998 terdapat 227 kasus, maka pada

${ }^{33}$ Wandita, Galuh., 2000, Air Mata Telah Terkuras, Kekerasan Belum Berakhir : Memahami Kekerasan Terhadap Perempuan sebagai Prasyarat sebuh Transformasi dalam Negara dan Kekerasan Terhadap Perempuan, Pengantar Kartini Syharir, Jakarta: Penerbit Yayasan Jurnal Perempuan.

${ }^{34}$ Anonim., 2000, Buruh Migran Perempuan: Pahlawan Devisa yang Teraniaya, http:// www.detik.com, 4 Agustus.

${ }^{35}$ Ibid.

${ }^{36}$ Ibid.

${ }^{37}$ Ibid.

${ }^{38}$ Anonim., 2000, Stop Kirim TKW mulai 17 Agustus, http: //www.detik.com/15 Agusttus. 
tahun 1999 terdapat 484 kasus. ${ }^{39}$ Data tersebut sejalan dengan data KBRI di Arab Saudi yang mencatat pemerkosaan terhadap TKW PRT pada tahun 1995 terdapat 59 kasus, pada tahun 1996 terdapat 363 kasus, tahun 1997 terdapat 506 kasus Jumlah kasus yang sesungguhnya terjadi mungkin jauh lebih tinggi, karena ada banyak kasus yang tidak dilaporkan korban..$^{40}$

Dalam korban pelanggaran HAM pun seringkali perempuan menjadi korban dari dua tindak pelanggaran HAM sekaligus. Pertama korban pelanggaran HAM itu sendiri, kedua korban pelanggaran HAM karena ia berjenis kelamin perempuan. Korban karena dia berjenis kelamin perempuan sebagaimana di atas dibahas sebagai ketidakadilan jender atau bias jender dalam penanganan korban tindak pelanggaran HAM.

\section{Agenda Aksi Pemberdayaan Perempuan}

Problematika perempuan dewasa ini tak dapat diselesaikan hanya pada level pribadi dan secara sporadis. Gerakan yang dilakukan oleh seorang individu, betapapun hebatnya, tanpa dukungan kelompok dan jaringan (networking) yang kuat, hanya akan sia-sia, bak teriakan di gurun pasir, dan mungkin menjadi martir yang tak berguna. Gerakan yang dimungkinkan haruslah bersifat holistiksistemik dan melibatkan jaringan organisasi yang banyak. Adapun modusmodus yang dapat dilakukan adalah:41
1. Reformasi : Pembaharuan di bidang hukum dengan didukung oleh penelitian dan tidak kalah pentingnya adalah inisiatif para perumus undang-undang yang berpihak pada hubungan emansipatif antara laki-laki dan perempuan.

2. Advokasi : Mengangkat kasus-kasus atau persoalan perempuan ke permukaan sehingga diperhatikan oleh para pengambil keputusan.

3. Edukasi : Pendidikan penyadaran tentang hak-hak perempuan di bidang sosial, budaya, politik dan ekonomi lewat mass media, latihan para legal, pendidikan hukum, pendapat umum dan sebagainya.

Memaknai tujuan pemberdayaan perempuan dalam hal ini menjadi sangat penting agar jelas artinya, yaitu: ${ }^{42}$

1. Menentang ideologi patriarki yaitu dominasi laki-laki atas perempuan.

2. Mengubah struktur dan pranata yang memperkuat dan melestarikan diskriminasi jender dan ketidaksamaan sosial ( keluarga, kasta, kelas, agama, proses dan pranata pendidikan, medial, praktik dan sistem kesehatan! perundang-undangan dan peraturan proses politik, model-model pembangunan dan pranta pemerintahan).

3. Memberi kemungkinan bagi perempuan miskin untuk memperoleh akses yaitu penguasaan atas sumber-sumber material dan informasi.

\footnotetext{
${ }^{39}$ Anonim., 2000, Ratusan TKW Diperkosa, http: //www.detik.com/Politik dan Peristiwa. 13 Agustus.

40Ibid.

${ }^{41}$ Safaat, Rachmad., 1994, Hak Azasi Manusia, Hukum dan Pemberdayaan Perempun Jurnal, Warta Studi Perempuan, Volume IV, Nomor 2.

${ }^{42}$ Setiawati, Trias., 2000,Pemberdayaan Perempuan di Masyarakat Madani, Contributing Paper, untuk Seminar Pemberdayaan manusia Menuju Masyarakat Madani di Jurusan Ilmu Penyuluhan Pembangunan PPS IPB, Bogor, 26-27 September
} 


\section{Pelaku Pemberdayaan}

1. Pemerintah: Di Berbagai sektor bidang pembangunan yang sangat luas sesungguhnya pemerintah mempunyai peranan yang besar untuk membatasi tindak pelanggaran HAM. Namun juga memiliki keterbatasan langkah di lapangan, karena koordinasi yang sulit, anggaran dan jangka waktu pelaksanaannya yang membelenggu. Indikator tindakan pelanggaran yang belum seragam bahkan kadang tidak dipahami, di samping kadang yang terjadi justru pemerintah melakukan 'pemerdayaan' dan menjadi pelaku tindak pelanggaran HAM terhadap perempuan

2. Organisasi Wanita: Di Kalangan Organisasi Wanita Efektif yang memiliki jumlah anggotanya yang besar, ada harapan merekalah yang akan melakukan pemberdayaan secara berkelanjutan dan massal. Namun sebagai kegiatan sampingan para anggota organisasi wanita juga memiliki keterbatasan waktu, keterbatasan dana, serta kurang profesional.

3. Perguruan Tinggi: Di Dunia Perguruan Tinggi dimana Tuntutan tridharma PT yang rata-rata masih mengedepankan penelitian kemudian pengajaran baru pengabdian masyarakat, maka menjadi sulit berharap bahwa pemberdayaan akan dimulai dari dosen, sokoguru di lembaga elit tersebut. Kaderisasi Pimpinan PT yang sensitif jender tidak selalu berkelanjutan menyebabkan perkembangan pemberdayaan perempuan tidak selalu meningkat, bahkan kadang mengalami kemandekan (stagnasi), dan bahkan mungkin penurunan (involusi). Kesinambungan program juga menjadi masalah yang penting karena para peminat kajian wanita dan jender juga menjadi sambilan saja- di samping disiplin ilmunya yang utama.
4. LSM: LSM -yang dimotori aktivis pria maupun perempuan- memang dikenal lebih profesional dan berkelanjutan dalam menangani pemberdayaan, karena memang umumnya didukung oleh pemberi dana dari dalam maupun luar negeri. Namun juga memiliki beberapa hal negatif, seperti ada cap "mengeksploitasi penderitaan rakyat" untuk mencari dana. Di samping juga sangat sulit sebuah program dapat terus berjalan ketika pendampingan dari LSM dilepaskan.

\section{Cara Pemberdayaan}

Ada beberapa cara yang dapat dilakukan, baik yang bersifat praktis yaitu bersifat jangka pendek dan insidental, ataupun yang bersifat strategis yaitu bersifat jangka panjang dan berkelanjutan. Pemenuhan kebutuhan jender praktis tersebut dapat membantu posisi perempuan menjadi lebih baik dalam jangka pendek, tetapi kurang membantu pemberdayaan dalam jangka panjang. Sementara pemenuhan kebutuhan jender strategis, kurang terasa manfaatnya dalam jangka pendek, tetapi terasa pengaruhnya dalam jangka panjang.

Program praktis misalnya proyek insidental mempunyai waktu sangat terbatas, serta kurang berarti bagi pemberdayaan perempuan, karena hanya akan memberdayakan secara sektoral yang kadang justru menambah beban perempuan. Program Strategis, misalnya program pendampingan memang dirasa lebih lebih sesuai untuk usaha pemberdayaan. Waktunya dapat mencapai lima tahunan. Mulai dari pengenalan lokasi, perumusan program-bersama masyarakat, pelaksanaan program, evaluasi, perumusan program lanjutan, evaluasi, program lanjutan. Maupun program lainnya sebagainya sampai suatu komunitas menjadi mandiri dengan pendekatan yang bersifat partisipatif. 


\section{Penutup}

Sebagai simpulan uraian di atas, maka dapat dikemukakan hal-hal sebagai berikut: 1. Jender atau isu-isu pemberdayaan perempuan lainnya telah lama dihembuskan, namun kenyataannya, masih menjadi slogan dan menjadi isu yang terpinggirkan dalam pembangunan di berbagai bidang.

2. Penggunaan perspektif jender dalam setiap permasalahan. Bias jender atau ketidakadilan jender yang akan diderita oleh kaum perempuan masih panjang, karena dalam hal ini diperlukan perspektif jender dalam setiap kebijakan, secara all out mulai

pengorganisasian, pelaksanaan, pengkoordinasian sampai dengan evaluasinya dalam setiap kasus pelanggaran HAM. Perspektif yang tidak hanya memenangkan kaum perempuan saja dan mengalahkan laki-laki, atau sebaliknya, memenangkan laki-laki dan terus 'menjajah' perempuan, tetapi hubungan antara laki-laki dan perempuan yang bersperspektif jender demi terwujudnya masyarakat yang sejahtera dan berkeadilan.

3. Peran serta dan kesadaran kaum lakilaki masih perlu ditingkatkan. Mengingat selama ini secara kultural posisi laki-laki lebih diuntungkan, meskipun ada halhal di mana kaum laki-laki juga dirugikan. Karena itu marilah mengutamakan dunia yang lebih adil.

4. Dalam pengelolaan dan pencegahan pelanggaran HAM, peran serta aktif perempuan dan laki-laki perlu lebih ditingkatkan, sehingga perempuan tidak menjadi korban dua kali, pertama korban pelanggaran HAM itu sendiri dan kedua menjadi korban kàrena berjenis kelamin perempuan.

5. Kelompok-kelompok yang berdaya di dalam masyarakat seperti Kelompok Convention Watch, LSM, LBH, Perguruan Tinggi diharapkan meningkatkan peranan dan jangkauannya untuk mensosialisasikan Konvensi Wanita.

6. Kelompok-kelompok strategis seperti penegak hukum, guru dan dosen, pemuka agama untuk mendapatkan prioritas sebagai agen perubahan (agent of change) dalam mengurangi tindak pelanggaran HAM terhadap perempuan.

7. Agenda aksi yang dilakukan oleh pelaku pemberdayaan perempuan, sebaiknya adalah kegiatan yang berkaitan secara langsung maupun tak langsung dengan bidang-bidang strategis pemberdayaan perempuan itu sendiri, yaitu: reformasi (perbaikan hukum), edukasi (pencerdasan kaum perempuan), dan advokasi (pembelaan terhadap kaum perempuan korban ketidakadilan).

\section{Daftar Pustaka}

Bahar, Saafroedin., 1996, Hak Asasi Manusia Analisis Komas HAM dan Jajaran Hankam/ ABRI, Jakarta: Sinar Harapan.

Ihromi, T.O, Irianto, S. dan Luhulima, A.S. (penyunting)., 2000, Penghapusan Diskriminasi Terhadap Wanita, Bandung: Penerbit Alumni.

Anonim. Tth. Landasan Aksi dan Deklarasi Beijing Persamaan Pembangunan Perdamaian. Forum Komunikasi Lembaga Swadaya Masyarakat untuk Perempuan dan Asosiasi Perempuan Indonesia untuk Keadilan.

Anonim, 2000, Rencana Induk Pembangunan Nasional Pemberdayaan Perempuan 2000 - 2004, Kantor Menteri Negara Pemberdayaan Perempuan RI, Jakarta, April.

Mary Astuti., 1997, "Jender dan Pembagunan", makalah, Penataran Metodologi Kajian Perempuan Berperspektif Jender, Dirjen Dikti, Yogyakarta.

Fakih, M., 1995, Menggeser konsep gender dan transformasi sosial, Yogyakarta: Pustaka Pelajar . 
Cook, EP., 1982, Psychological Androgyny, New York: Pergamon Press.

Donelson, E., \& Gullahom, J.E., 1977, Women: A Psychological perspective. New York: John Wilwy and Sons, Inc.

Barnhause, R. T., 1988, Identitas Wanita, Yogyakarta : Kanisius

Weiten,W., 1992, Psychology: Themes and Variations. California Brooks/Cole Publishing Company.

Nuriyah, Sinta., 2000. Kata Sambutan Buku Negara dan Kekerasan terhadap Perempuan, Pengantar Kartini Syharir, Penerbit Yayasan Jurnal Perempuan, Jakarta.

Arifin, Nurul., 2000, Puisi pada Ceramah pada Acara Nugerah Perempuan dan Peluncuran Buku: Negara dan Kekerasan terhadap Perempuan, http://www.detik.com/ bintang>bisikbisik, 21 Juni.

Fuad, Chairil., 200o, Kekerasan Rumah Tangga Sulit Terjerat Hukum, makalah dalam Seminar dan Lokakarya Pentingnya Perlindungan Bagi Korban Kekerasan dalam Rumah Tangga, http: //www.detik.com/Politik dan Peristiwa. 3 Juni

Nursyahbani K, Ketidakadilan dan Isu SARA Ciptakan Kerusuhan, http: // www.detik.com/Politik dan Peristiwa, 21 Juni 2000.
Mely. G.Tan., Ceramah pada Acara Nugerah Perempuan dan Peluncuran Buku: Negara dan Kekerasan terhadap Perempuan, http://www.detik.com/ bintang $>$ bisik-bisik, 21 Juni 2000

Nuriyah, Sinta., 200o,Ceramah pada Acara Nugerah Perempuan dan Peluncuran Buku: Negara dan Kekerasan terhadap Perempuan, http://www.detik.com/ bintang>bisikbisik. 25 April.

Parawansa, Khofifah Indar., 200o, dialog Menneg PP RI dengan Gubernur Kalbar, http: //www.detik.com/Politik dan Peristiwa, 15 Desember, 15 Desember.

${ }^{33}$ Wandita, Galuh., 2000, Air Mata Telah Terkuras, Kekerasan Belum Berakhir : Memahami Kekerasan Terhadap Perempuan sebagai Prasyarat sebuh Transformasi dalam Negara dan Kekerasan Terhadap Perempuan, Pengantar Kartini Syahrir, Jakarta: Penerbit Yayasan Jurnal Perempuan.

Safaat, Rachmad., 1994, Hak Azasi Manusia, Hukum dan Pemberdayaan Perempun, Jurnal, Warta Studi Perempuan, Volume IV, Nomor 2.

Setiawati, Trias., 2000,Pemberdayaan Perempuan di Masyarakat Madani, Contributing Paper, untuk Seminar Pemberdayaan manusia Menuju Masyarakat Madani di Jurusan IImu Penyuluhan Pembangunan PPS IPB, Bogor, 26-27 September. 